\title{
Simulation of pomegranate (Punica granatum L.) growth and yield under different climatic conditions, water and soils using crop simulation models in Egypt.
}

\section{Ibrahim Eldesouki Arafat*, Safia Abd Elmonem Abo Taleb and Mohamed Abou El-Wafa Ahmed}

\author{
Horticulture Research Institute, Agriculture Research Center, Egypt \\ *corresponding auther email: z82elari80@ gmail.com
}

Received on: 20/10/2019

Accepted on:18/12/2019

\begin{abstract}
Crop simulation models (CSM) are now widely used to predict the future crop yields, to find the suitable measures for increase the crops productivity and to simulate the potential effects of genetic characteristics, irrigation water, soil and climatic conditions, together with the management practices on yield. The objective of this work is to evaluate the ability of AquaCrop model to simulate growth and yield of pomegranate under different climatic conditions, soil and irrigation water. Experiments were conducted during 2016 and 2017 seasons in tow governorates of Egypt (ElBehera and North of Sinai). The data required to run the AquaCrop model relate to climate were obtained from the America's space agency (NASA) and the physical and chemical characteristics of soil and irrigation water for different study locations were obtained from field sample analysis of soil and irrigation water. The validation and calibration of model was performed using field observations relative to yield data in 2016 and 2017. The results show the observed values of pomegranate yield in the field were greater than the simulated values in two seasons of study $28.543,30.433$ for first location of study (ElBehera) respectively and 10.638, 10.978 ton/ha for second location of study (North of Sinai) respectively, but the differences between them were very low. The averages of annual climatic data have the most significant impact on pomegranate yield. The agreement between observed and simulated yield data was good with root mean square error (RMSE), index of agreement (D) and coefficient of determination $\left(R^{r}\right)$. Statistical indicators, RMSE, D and $\mathrm{R}^{r}$ confirmed that the model is very reliable for simulating pomegranate yield for experiments (ElBehera and North of Sinai) in 2016 and 2017 seasons (low RMSE, D and $\mathrm{R}^{r}$ near 1), The relationship between observed and simulated yield produced RMSE ranged from 0.53 to $9.11 \%$, D ranged from 0.985 to 0.994 and $\left(R^{r}\right)=0.99$. It was concluded that calibrated AquaCrop model was able to simulate growth and yield of pomegranate in tow experiments.
\end{abstract}

\section{INTRODUCTION}

The pomegranate (Punica granatum L.), is a crop that grows in all soil types and diverse climates (from semi-arid temperate zones to subtropical climates); they are widely cultivated in Asia, and the Mediterranean countries such as
Egypt, Tunisia, Morocco, Turkey and Spain Levin, (2006), Jalikop, (2007), El-Falleh et al., (2009) and Ahmet et al., (2009). In Egypt the production of pomegranate is concentrated in four governorates Assiut, Sohag, ElBehera and North Sinai Salman et 


\section{Scientific Journal of Agricultural Sciences 1 (2): 32-42, 2019}

al., (2016); recent statistics data provided by the Ministry of Agriculture in 2018 indicate that a total of 79040 fadan are planted with pomegranate trees, with a total production of 382587 tons (annual report of ministry of agriculture and land reclamation 2018).

$P$. granatum crop yields simulation is certainly a complicated task, it is affected by a multitude of variables (soil, meteorology, nutrients, pests, management, etc.), many of them, in turn, difficult to model.
AquaCrop is a simulation model designed by FAO for the analysis of the productivity of different crops in diverse agro-ecosystems Steduto et al., (2009) fig 1 is application being possible for a wide range of ecological conditions and production systems. This model integrates the effect of genetic characteristics, fertilization, soil and climatic variables, together with the management variables, to simulate crop production in response to water in the soil-plant system Geerts et al., (2010).

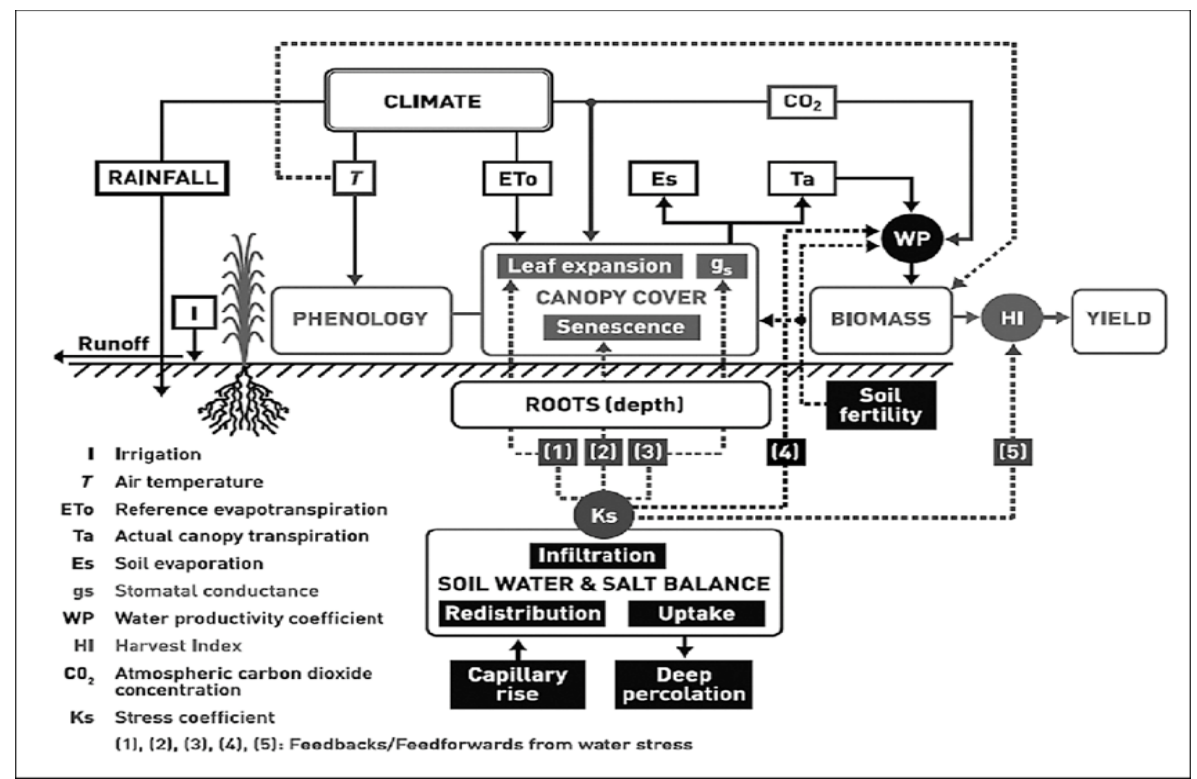

Fig1. Diagram of AquaCrop modeling Source: Steduto et al., (2012).

The data required by the AquaCrop program includes climate (maximum temperature (Tmax), minimum temperature (Tmin), Relative humidity(RH), Wind speed (WS), Solar radiation (SR), precipitation $(\mathrm{P}), \quad$ reference evapotranspiration (ETo) and an average annual concentration of $\mathrm{CO}_{2}$, according to observatory measurements in Mauna Loa,
Hawaii.), crop, soil, and management data. With this information, the program predicts the daily production of biomass and the final yield of crop, in our case of the pomegranate.

The objective of this work is evaluated the AquaCrop model to simulate growth and yield of pomegranate under different climatic conditions, soil and irrigation water in Egypt during 2016 and 2017. 


\section{Ibrahim Eldesouki Arafat et al., 2019}

\section{MATERIALS METHODS}

\subsection{The Field Experimental Site:}

Experiments were conducted during 2016 and 2017 seasons in tow governorates located in the north of Egypt, private farm located at the 64 $\mathrm{km}$ on the Cairo-Alexandria desert road, ElBehera (latitude $30.47{ }^{\circ} \mathrm{N}$, longitude $30.09^{\circ} \mathrm{E}, 94.5 \mathrm{~m}$ above sea level) and experimental farm of $\mathrm{El}$
Maghara Station of Desert Research Center, North of Sinai (latitude $30.35^{\circ} \mathrm{N}$, longitude $33.20^{\circ} \mathrm{E}, 414.15 \mathrm{~m}$ above sea level). Respect to the experiments characteristics were obtained from previous studies Bakeer, (2009), Seidhom and Abd-ElRahman, (2011), Shaheen et al., (2016), Salama et al., (2016) and Farag et al., (2017) table 1.

Table 1. Characteristics of experiments.

\begin{tabular}{lll}
\hline Character & ElBehera & North of Sinai
\end{tabular}

Planting distances

$$
3 \times 3
$$

Wonderful

5

Drip

$100 \%\left(11404 \mathrm{~m}^{3} / \mathrm{ha}\right)$.
$3.6 \times 3.6$

Manfalouty

Drip

\section{Irrigation water} levels

$100 \%(114)$

*according to the extensions of the Minis
With respect to fertilization on ElBehera, organic manure in December at $75 \mathrm{~kg} /$ tree were added and mineral fertilization of (NPK) were added at $2 \mathrm{~kg} /$ tree ammonium sulfate $(20.6 \%)$ in two doses in March and May after the fruit eased, $1 \mathrm{~kg} /$ tree superphosphate $(15 \%)$ in December and from $500 \mathrm{~g} /$ tree potassium sulfate (48\%) in March). On North of Sinai, plants were fertilized by Organic manure in December at $100 \mathrm{~kg} / \mathrm{tree}$ and mineral fertilization of (NPK) were used as $3.5 \mathrm{~kg} /$ tree ammonium sulfate $(20.6 \%)$ in two doses in March and May after the fruit eased, $2 \mathrm{~kg} /$ tree superphosphate $(15 \%)$ in December and from $1 \mathrm{~kg} / \mathrm{tree}$ potassium sulfate (48\%) in March). griculture, Egypt (2015).

\subsection{Weather data:}

The weather data were obtained from the website of the America's space agency (NASA https://power.larc.nasa.gov/dataaccess-viewer/). Data in Table 2 and 3 shows the average of annual weather data (maximum air temperature, minimum air temperature, wind speed, relative humidity, solar radiation and evapotranspiration (ETo) for study locations (ElBehera and North of Sinai) during the period $201^{\circ}$ to 2017. Respect to the evapotranspiration (ETo) data was calculated using the FAO PenmanMonteith equation as described by Allen et al., (1998). 
Scientific Journal of Agricultural Sciences 1 (2): 32-42, 2019

Table 2. Average of annual weather data of the experiment site at ElBehera during the period 2015 - 2017 growing seasons.

\begin{tabular}{|c|c|c|c|}
\hline Weather Data & 2015 & 2016 & 2017 \\
\hline Max. air temperature $\left(\operatorname{Tmin}^{\circ} \mathrm{C}\right)$ & 28.61 & 29.11 & 28.06 \\
\hline Min. air temperature $\left(\operatorname{Tmin}^{\circ} \mathbf{C}\right)$ & 14.95 & 14.98 & 14.22 \\
\hline Relative humidity (\%) & 52.13 & 52.24 & 55.40 \\
\hline Wind speed ( km/day) & 2.93 & 2.94 & 2.76 \\
\hline Solar radiation $\left(\mathrm{MJ} / \mathrm{m}^{2}\right.$.day $)$ & 20.62 & 20.86 & 20.88 \\
\hline Precipitation ( $\mathrm{mm} \mathrm{day}^{-1}$ ) & 0.21 & 0.59 & 0.47 \\
\hline Evapotranspiration (ETo) $\mathrm{mm} / \mathrm{day}$ & 3.03 & 3.16 & 3.12 \\
\hline
\end{tabular}

Table 3. Average of annual weather data of the experiment site at North of Sinai during the period $2015-2017$ growing seasons.

\begin{tabular}{|c|c|c|c|}
\hline Weather Data & 2015 & 2016 & 2017 \\
\hline Max. air temperature $\left(\operatorname{Tmin}^{\circ} \mathbf{C}\right)$ & 26.31 & 26.92 & 26.19 \\
\hline Min. air temperature $\left(\operatorname{Tmin}^{\circ} \mathrm{C}\right)$ & 13.5 & 13.61 & 13.15 \\
\hline Relative humidity (\%) & 54.17 & 53.54 & 55.29 \\
\hline Wind speed ( km/day) & 2.94 & 2.97 & 2.78 \\
\hline Solar radiation $\left(\mathrm{MJ} / \mathrm{m}^{2}\right.$.day $)$ & 21.3 . & 21.32 & 21.27 \\
\hline Precipitation ( mm day $\left.^{-1}\right)$ & 0.21 & 0.43 & 0.18 \\
\hline Evapotranspiration (ETo) $\mathrm{mm} / \mathrm{day}$ & 3.08 & 3.09 & 3.07 \\
\hline
\end{tabular}

\subsection{Soil Data:}

The physical and chemical characteristics of soil for different study locations (ElBehera and North of Sinai) were collected from previous studies Bakeer, (2009), Seidhom and Abd-El-Rahman, (2011), Shaheen et al., (2016), Salama et al., (2016) and Farag et al., (2017) table 4.

\subsection{Irrigation water Data:}

Data of chemical composition of irrigation water for different study locations (ElBehera and North of Sinai) were obtained from previous studies Bakeer, (2009), Seidhom and Abd-El-Rahman, (2011), Shaheen et al., (2016), Salama et al., (2016) and Farag et al., (2017) table 5.

\subsection{AquaCrop Input Data:}

The AquaCrop model (version 6.1) was used and evaluated in the current study to simulate growth and yield of pomegranate in two Egyptian governorates (ElBehera and North of Sinai) during 2016 and 2017.

The input data and parameters for AquaCrop are shown in Fig 2. The weather data include maximum air temperature, minimum air temperature, wind speed, relative humidity, solar radiation, evapotranspiration and $\mathrm{CO}_{2}$ concentration. The management, soil, irrigation water characteristics and cultivar parameters.

\subsection{Model Calibration and Testing:}

During calibration, certain model parameters were adjusted to make the simulation results match the observed values. Some of the parameters were used in the calibration during the experiment, such as observations of phenological stages of the crop (days to maximum canopy cover CC, duration of flowering and days to 
Table 4. Mean physical and chemical characteristics of the 0-60 $\mathrm{cm}$ depth ElBehera and North of Sinai soil layer.

\begin{tabular}{|c|c|c|}
\hline Parameter & EIBehera & North of Sinai \\
\hline \multicolumn{3}{|c|}{ Particle size distribution \% } \\
\hline Sand & 85.20 & 98.25 \\
\hline Salt & 8.63 & 0.90 \\
\hline Clay & 6.17 & 0.85 \\
\hline Texture class & Loamy sand & Sand \\
\hline Bulk Density $\left(\mathrm{g} / \mathrm{cm}^{-3}\right)$ & 1.68 & 1.50 \\
\hline Organic matter \% & 0.06 & 0.23 \\
\hline Field Capacity (\%) & $12.6 \cdot$ & 10.1 . \\
\hline Wilting Point (\%) & 4.38 & 4.48 \\
\hline $\mathrm{CaCO3}$ & 17.5 & 4.85 \\
\hline pH & 7.71 & 7.7 . \\
\hline E.C. $\left(\mathrm{dSm}^{-1}\right)$ & 3.03 & 0.65 \\
\hline \multicolumn{3}{|c|}{ Soluble cations $\left(\mathrm{meq} / \mathrm{L}^{-1}\right)$} \\
\hline $\mathrm{Ca}^{+}$ & 8.88 & 2.75 \\
\hline $\mathbf{K}^{+}$ & 0.98 & 0.06 \\
\hline $\mathrm{Na}^{+}$ & 12.8 & 1.42 \\
\hline $\mathbf{M g}^{+}$ & 7.65 & 1.75 \\
\hline \multicolumn{3}{|c|}{ Soluble anions $\left(\mathrm{meq} / \mathrm{L}^{-1}\right)$} \\
\hline $\mathrm{Cl}^{-}$ & 14.9 & 1.70 \\
\hline $\mathrm{SO}^{2-}$ & 3.60 & 2.48 \\
\hline $\mathrm{HCO}^{3-}$ & 11.80 & 1.80 \\
\hline $\mathrm{CO3}^{2-}$ & \multicolumn{2}{|c|}{ Not detected } \\
\hline
\end{tabular}

Table 5. Chemical composition of the EIBehera and North of Sinai water used for irrigation.

\begin{tabular}{|c|c|c|}
\hline Parameter & ElBehera & North of Sinai \\
\hline pH & 6.50 & 8.36 \\
\hline E.C. $\mathrm{dSm}^{-1}$ & 6.44 & 4.99 \\
\hline \multicolumn{3}{|c|}{ Soluble cations $\left(\mathrm{meq} / \mathrm{L}^{-1}\right)$} \\
\hline $\mathrm{Ca}^{+}$ & 20.40 & 13.33 \\
\hline $\mathbf{M g 2}^{+}$ & 8.95 & 5.78 \\
\hline $\mathrm{Na}^{+}$ & 33.00 & 25.33 \\
\hline $\mathbf{K}^{+}$ & 2.01 & 1.15 \\
\hline \multicolumn{3}{|c|}{ Soluble anions $\left(\mathrm{meq} / \mathrm{L}^{-1}\right)$} \\
\hline $\mathrm{CO32}^{-}$ & 0.00 & 0.00 \\
\hline $\mathrm{HCO}^{3-}$ & 20.5 & 7.44 \\
\hline $\mathrm{Cl}^{-}$ & 39.30 & 4.49 \\
\hline $\mathrm{SO}^{2-}$ & 4.59 & 33.66 \\
\hline
\end{tabular}


Scientific Journal of Agricultural Sciences 1 (2): 32-42, 2019

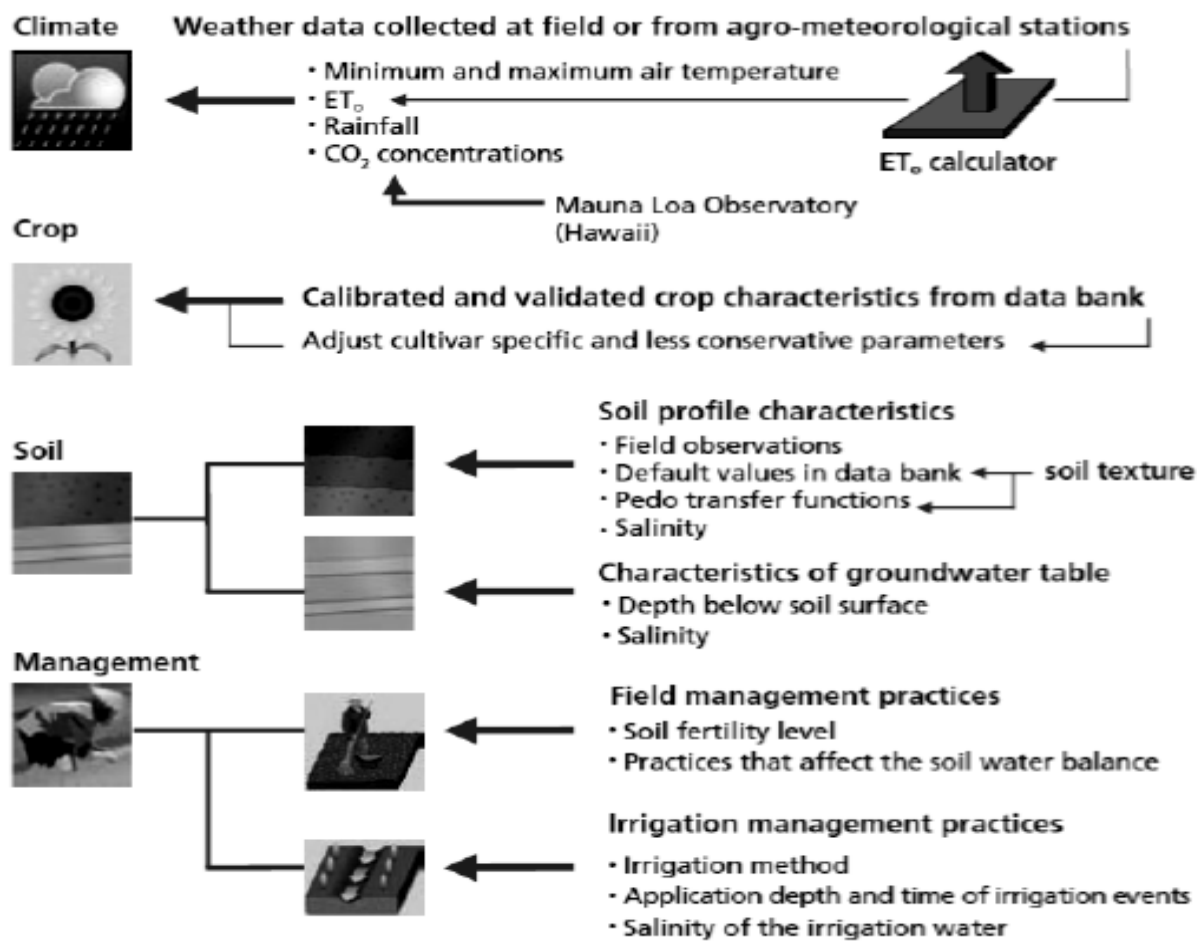

Fig 2. Input data and parameters for AquaCrop model Source: Steduto et al., (2012).

Table 6.Calibration of the variables of the AquaCrop modules

\begin{tabular}{lll}
\hline Parameters & \multicolumn{1}{c}{ ElBehera } & \multicolumn{1}{c}{ North of Sinai } \\
\hline Days to harvest & 225 days & 202 days \\
Days to maximum canopy cover & 39 days & 37 days \\
Duration of flowering & 63 days & 60 days \\
Maximum canopy cover & $3.7 \mathrm{~m}^{3} /$ tree & $10 \mathrm{~m}^{3} / \mathrm{tree}$ \\
Plant density & $1111 \mathrm{tree} / \mathrm{ha}$ & $772 \mathrm{tree} / \mathrm{ha}$ \\
Hydraulic conductivity & $1.9 \times 10^{-3} \mathrm{~cm} / \mathrm{sec}^{-1}$ & $0.72 \times 10^{-4} \mathrm{~cm} \mathrm{sec}^{-1}$ \\
Water holding capacity WHC & $28.1 \%$ & $22.3 \%$ \\
Reference harvest index HI & $61.23 \%$ & $60.6 \%$ \\
Crop coefficient KC & 0.65 & 0.63 \\
\hline
\end{tabular}

harvest), hydraulic conductivity, water holding capacity, reference harvest index $\mathrm{HI}$ and crop coefficient KC Table 6.

Performance of AquaCrop in simulating yield was evaluated by comparing simulated results against observed data. The statistical indices used in the validation were correlation coefficient (r), root mean square error (RMSE) and willmott index of agreement (d) Willmott (1981) Samiha Ouda et al., (2015).

The correlation coefficient $(r)$ is an indicator of degree of closeness between simulated and observed data. 


\section{Ibrahim Eldesouki Arafat et al., 2019}

It ranges from 0 to 1 , with values close to 1 indicating a good agreement, and typically values

greater than 0.50 are considered acceptable in simulations Moriasi et al., (2007).

The correlation coefficient was calculated using the following equation:

$$
r=\frac{\sum_{i=1}^{n}\left(O_{i}-M O\right) \times\left(S_{i}-M S\right)}{\sqrt{\sum_{i=1}^{n}\left(O_{i}-M O\right)^{2} \times \sum_{i=1}^{n}\left(S_{i}-M S\right)^{2}}}
$$

Where:

$\mathrm{O}_{\mathrm{i}}$ observed value, $\mathrm{S}_{\mathrm{i}}$ simulated value, MO mean of observed values and MS mean of simulated values.

The root mean square error (RMSE) is a measure to calculate the total or mean deviation between the observed and simulated values. The adjustment of the model improves when the value is close to zero. The root mean square error (RMSE) was estimated by the following equation Loague and Green (1991):

$$
R M S E=\sqrt{\frac{\sum_{i=1}^{n}\left(O_{i}-S_{i}\right)^{2}}{N}}
$$

Where:

$\mathrm{S}_{\mathrm{i}}$ simulated value, $\mathrm{O}_{\mathrm{i}}$ observed value and $\mathrm{N}$ number of observations.

The index of agreement (d) is a measure of the relative error in the model estimates. It is a dimensionless number that ranges between 0 and 1 , with 0 indicating no agreement and 1 indicating a perfect agreement between the simulated and observed data Krause et al., (2005). The index of agreement (d) was calculated using the Willmott et al., (1985) equation:

$$
d=1-\frac{\sum_{i=1}^{n}\left(O_{i}-S_{i}\right)^{2}}{\sum_{i=1}^{n}\left(\left|S_{i}-M O\right|+\left|O_{i}-M O\right|\right)^{2}}
$$

Where:

$\mathrm{O}_{\mathrm{i}}$ observed value, $\mathrm{S}_{\mathrm{i}}$ simulated value and MO mean of observed values.

\section{Results and Discussions.}

The pomegranate yield data obtained from the field and AquaCrop module are shown in table 8. In experiments 2016 and 2017, the observed values in the field were greater than the simulated values $28.543,30.433,10.638$ and 10.944 ton/ha respectively, but the difference between them was very low.

Table 8. Observed and simulated pomegranate yield data obtained in tow experiments (EIBehera and North of Sinai) during 2016 and 2017.

\begin{tabular}{lcccccc}
\hline \multirow{2}{*}{ Season } & \multicolumn{3}{c}{ ElBehera } & \multicolumn{3}{c}{ North of Sinai } \\
\cline { 2 - 7 } & $\begin{array}{c}\text { Observed } \\
\text { Ton/ha }\end{array}$ & $\begin{array}{c}\text { Simulated } \\
\text { Ton/ha }\end{array}$ & $\begin{array}{c}\text { D* } \\
\text { Ton/ha }\end{array}$ & $\begin{array}{c}\text { Observed } \\
\text { Ton/ha }\end{array}$ & $\begin{array}{c}\text { Simulated } \\
\text { Ton/ha }\end{array}$ & $\begin{array}{c}\text { D* } \\
\text { Ton/ha }\end{array}$ \\
\hline $\mathbf{2 0 1 5 -}$ & 28.543 & 28.324 & 219 & 10.638 & 10.588 & 50 \\
$\mathbf{2 0 1 6}$ & & & & & & \\
$\mathbf{2 0 1 6 -}$ & 30.433 & 30.421 & 12 & 10.978 & 10.944 & 34 \\
$\mathbf{2 0 1 7}$ & & & & & & \\
\hline
\end{tabular}

* Difference between the observed and simulated values. 


\section{Scientific Journal of Agricultural Sciences 1 (2): 32-42, 2019}

In general, statistical indicators express a good fit between the observed and simulated values. As shown in fig 3 , the model simulated crop yields in an acceptable form for a wide range of agroecological conditions with a correlation coefficient $(\mathrm{r})=.99$ for tow experiments (ElBehera and North of Sinai).

According to the values of root mean squared error (RMSE) for tow experiments (ElBehera and North of Sinai), indicated in table 9 , the differences between observed and simulated values varied between 0.043 and 0.155 Ton/.ha, which represents, in average percentage terms for tow experiments, $4.82 \%$.

Finally, the data of the index of agreement (Willmott 1981 and Willmott 1982) for tow experiments indicating a perfect agreement between the simulated and observed data table 9. Similar results were obtained by Ismail et al., (2015) on peach trees.

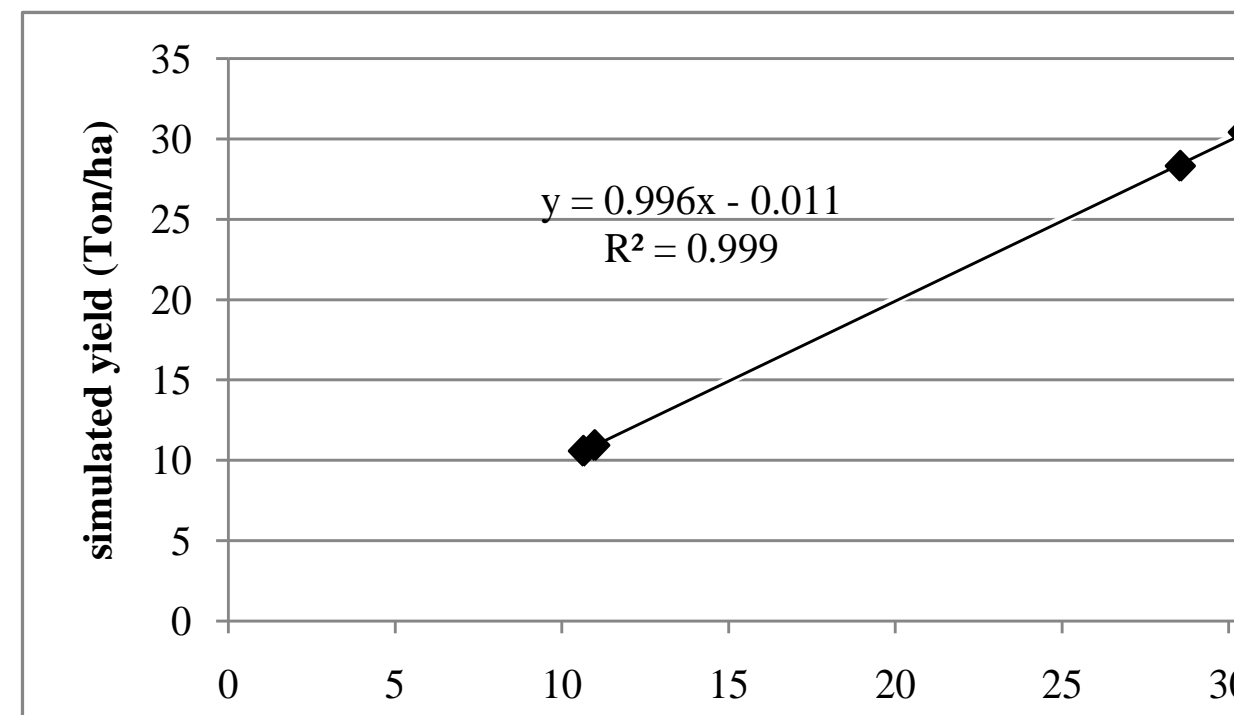

Fig 3. Relation between observed and simulated values of the pomegranate yield obtained in tow experiments (EIBehera and North of Sinai) during 2016 and 2017.

Table 9. Statistical indices derived for evaluating the performance of AquaCrop model in simulating pomegranate yield in tow experiments (ElBehera and North of Sinai) during 2016 and 2017.

\begin{tabular}{|c|c|c|c|c|c|c|}
\hline \multirow{3}{*}{ Season } & \multicolumn{3}{|c|}{ ElBehera } & \multicolumn{3}{|c|}{ North of Sinai } \\
\hline & \multicolumn{2}{|c|}{ RMSE* } & \multirow[b]{2}{*}{$d^{*}$} & \multicolumn{2}{|c|}{ RMSE* } & \multirow[b]{2}{*}{$\mathrm{d}^{*}$} \\
\hline & Ton/ha & $\%$ & & Ton/ha & $\%$ & \\
\hline $\begin{array}{l}2015-2016 \\
2016-2017\end{array}$ & 0.155 & 0.53 & 0.994 & 0.043 & 9.11 & 0.985 \\
\hline
\end{tabular}




\section{Ibrahim Eldesouki Arafat et al., 2019}

\section{Conclusions}

The AquaCrop model was able to simulate growth and yield of pomegranate in tow experiments.

\section{REFERENCES}

Ahmet D, Duman O, Mustafa D, Kenan E N, and Coskun D (2009). Antimicrobial activity of six pomegranate varieties and their relation to some of their pomological and phytonutrient characteristics. Molecules, 14 (5),1808-1817.

Allen RG, Pereira LS, Raes D and Smith M (1998). Crop evapotranspiration: guidelines for computing crop requirements. FAO Irrigation and Drainage Paper No. 56. FAO, Rome, Italy.

Bakeer SM (2009). Water use efficiency and soil management practices for Manfalouty pomegranate trees under EL-Maghara conditions. Ph.D. Thesis. Faculty of Environmental Agricultural Sciences at El-Arish, Suez Canal University, Ismailia, Egypt, pp 130.

Ismail SM, Zin El-Abedin TK, ElAnsary DO and Abd El-Al A (2015). Modification of fao crop model to simulate yield response to water for peach trees. Misr J. Ag. Eng., 32 (1), 145 - 172.

El-falleh W, Nasri N, Marzougui N, Thabti I, M'rabbet A, Yahya Y, Lachiheb B, Guasmi $F$ and Ferchichi A (2009). Physio-chemical properties of some local pomgranate (Punica granatum L.). International Journal of Food Science and Nutrition, 60 (2), 197-2010.

Farag AA, Eltaweel AA, AbdElrahman SH, Ali AA and Ahmed MSM (2017). Irrigation Regime and Soil Conditioner to Improve Soil Properties and Pomegranate Production in Newly Reclaimed
Sandy Soil. Asian Journal of Soil Science and Plant Nutrition. 1(2), 118.

Geerts S, Raes D and Garcia $M$ (2010). Using AquaCrop to derive deficit irrigation schedules. Agric. Water Manage. 98 (1), 213-216.

Jalikop SH (2007). Linked dominant alleles or inter-locus interaction results in a major shift in pomegranate fruit acidity of 'Ganesh' $\mathrm{x}$ 'Kabul Yellow'. Euphytica, 158 (1-2), 201207.

Krause P, Boyle DP and Base F (2005). Comparison of different efficiency criteria for hydrological model assessment. Advances in Geosciences 5: 89-97.

Levin GM.(2006) ."Pomegranate Roads: a Soviet Botanist's Exile from Eden", 1st ed., Floreant Press, Forestville, California, pp. 15-183.

Loague $K$ and Green RE (1991). Statistical and graphical methods for evaluating solute transport models; overview and application. J. Contam. Hydrol, 7(1-2):51 73.

Ministry of agriculture and land reclamation, Agricultural Research Center, Egypt (2015). The pomegranate. Agrarian Culture. Technical bulletin No 4 .

Ministry of agriculture and land reclamation (2018) cultivation and production of pomegranate. Report, https://almalnews.com.

Moriasi DN, Arnold JG, Van Liew MW, Binger RL, Harmel RD and Veith TL (2007). Model evaluation guidelines for systematic quantification of accuracy in watershed simulations. Transactions of the ASABE, 50 (3), 885-900.

Salama ASM and Elsherbeny RA (2016). Influence of Growth Regulators Treatments on Suckers 
Scientific Journal of Agricultural Sciences 1 (2): 32-42, 2019

Growth Control, Yield and Fruit Quality of Pomegranate Trees cv. Manfalouty and Their Economics Effect. Journal of Agriculture and Veterinary Science. 9 (1): 73-82.

Salman ANME and Mustafa Y.S. (2016). Economic Efficiency Indicators for Production and Marketing of Pomegranate in Egypt. j. Agric. Econom. and Social Sci., Mansoura Univ., 7 (6): 633 - 641.

Samiha Ouda, Morsy M, Sayad T. and El Hussieny F (2015). Parameterization of cropsyst model for four wheat cultivars grown in Egypt. 2 (6), 851-861.

Seidhom SH and Abd-El-Rahman G (2011). Prediction of Traditional Climatic Changes Effect on Pomegranate Trees Under Desert Condition in ELMaghara, Egypt. Journal of American Science, 7(5), 268-280.

Shaheen SA, Ali AA and El-Bolok TK (2016). Improving Pomegranate Fruit Quality by Using Some Practices. Egypt. J. Hort.Vol. 43(2), 259 -276.
Steduto P, Hsiao TC, Raes D and Fereres E (2009). AquaCrop - the FAO crop model to simulate yield response to water: I. Concepts and underlying principles. Agronomy Journal. 101: 426-437.

Steduto P, Hsiao TC, Fereres E and Raes D (2012). Crop yield response to water. FAO Irrigation and Drainage Paper No. 66 Food and Agriculture Organization of the United Nations, Rome, Italy.

Willmott CJ (1981). On the Validation of Models. Physical Geography, 2(2), 184-194.

Willmott CJ (1982). Some Comments on the Evaluation of Model Performance. Bulletin of the American Meteorological Society, 63, 1309-1313.

Willmott CJ, Ackleson SG, Davis RE, Feddema JJ, Klink KM, Legates DR, O'Donnell J and Rowe CM (1985). Statistics for the evaluation and comparison of models. J. Geophys. Res. 90 (c5), 8995 9005. 


\title{
Ibrahim Eldesouki Arafat et al., 2019
}

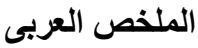

\section{التببؤ بنمو وانتاج الرمان تحت ظروف مختلفه من المناخ ، الماءو و التربه بواسطة استخدام نظم المحاكاه للمحاصيل في مصن مصر. ابراهيم الاسوقى عرفات و صفية عبد المنعم ابوطالب و محمد ابو الوفا احمد

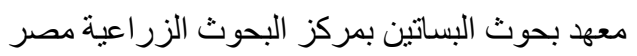

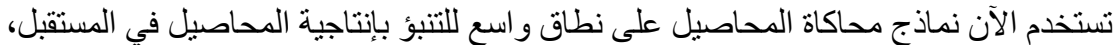

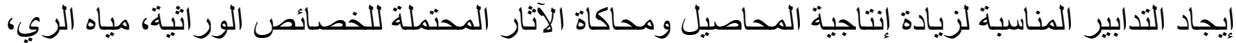

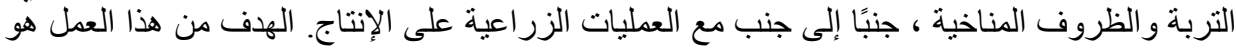

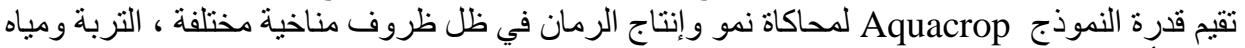

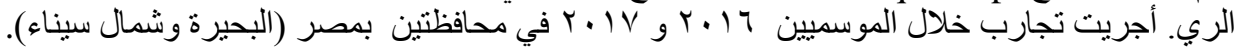

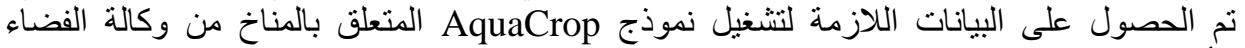

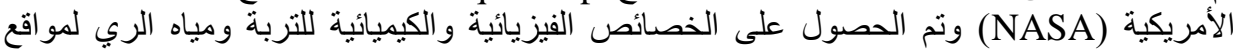

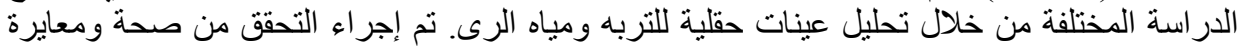

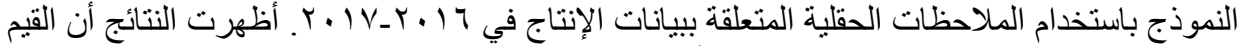

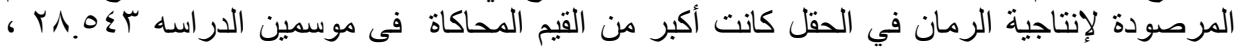

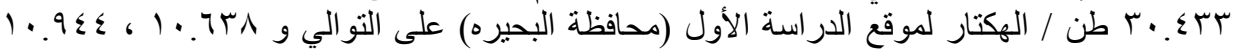

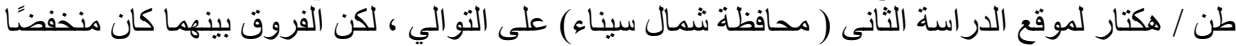

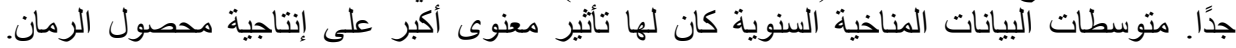

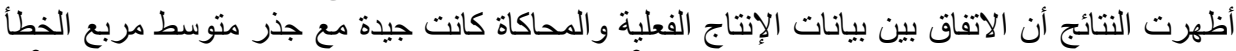

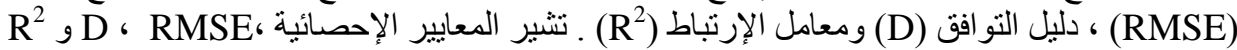

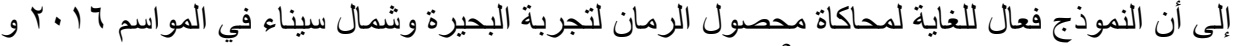

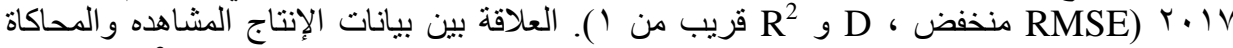

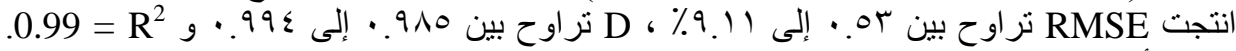
استتتج أن النموذج AquaCrop المعايير كان قادرًا على محاكاة نمو و إنتاجية الرمان فى في التجريتين. 